\title{
GIS BASED EVALUATION OF GROUNDWATER QUALITY OF WESTERN LAHORE USING WATER QUALITY INDEX
}

\author{
Zaib-Un-Nisa*, Fatima Imtiaz, Iftikhar Ahmad and Sajid Rashid Ahmad \\ College of Earth and Environmental Sciences, University of the Punjab, Lahore, Pakistan \\ "Corresponding author's e-mail: dr_zaib8@yahoo.com
}

\begin{abstract}
Water is one of the basic necessities to survive on earth, access to clean drinking water is the right of every human being but unfortunately water resources are getting polluted due to industrialization, improper management of waste and overpopulation. The objective of this research is to evaluate drinking water quality in Western Lahore. For convenience in sample collection the area under observation was divided into six zones and a total number of 72 drinking water samples were obtained and put to wide-ranging physicochemical analysis. Each sample was tested for 12 parameters including $\mathrm{pH}$, turbidity, total dissolved solids (TDS), electrical conductivity (EC), Total Hardness, Calcium, Magnesium, total Alkalinity, Chloride, Nitrate, Carbonate and bicarbonate. The outcomes were compared with standards of World Health organization (WHO) and national standards for drinking water quality (NSDWQ). Inverse Distance Weighted (IDW) technique was used to create zone wise maps within GIS environment. At last Water Quality Index (WQI) was calculated to discover the fitness of water for human consumption. The results showed that TDS in $11 \mathrm{Z5}$ (1099.2 ppm), EC in 8Z1 (119.8 ppm), $10 \mathrm{Z1} \mathrm{(113.2} \mathrm{ppm),} 7 \mathrm{Z2}$ (132.4 ppm), $10 \mathrm{Z2}$ (138.9 ppm), $11 Z 5$ (174.5 ppm), $1 Z 6$ (114.8 ppm) and Calcium (296 ppm) in 3Z3 are exceeding the permissible limits. Moreover, samples from 8Z2, 8Z4, $11 \mathrm{Z5}$ and $12 \mathrm{Z} 5$ have poor WQI. So, water from these locations is unfit for human consumption and need better water quality management.
\end{abstract}

Keywords: Drinking water, water aquifer, water resource management, inverse distance weighted, water quality index, physicochemical.

\section{INTRODUCTION}

Water is a finite resource on earth but it is the basic requirement for the sustainability of all living beings on this planet (Ashraf et al., 2015). Multiple factors like population growth, urbanization, economic growth and change in climate patterns have contributed in the increase of water scarcity all over the world and as a result water resource management has become a global issue (Haque at el., 2014; House and Chang, 2011). Surface water is not sufficient to fulfil all the human needs; groundwater is the only resource to meet ever increasing demand of water. In many countries, groundwater is being used for agriculture, domestic and industrial purposes. It is now estimated that $70 \%$ of water is abstracted for irrigation purpose (Water, 2009). The most appropriate and widely used source of drinking water is groundwater, but due to anthropogenic activities its quality is getting inferior day by day (Ashraf et al., 2015). Drinking water should be essentially clean from components that have bad impacts on human health. These components can be physical (colour and odour), chemical (minerals and organic substances) or biological (microorganisms).

Provision of safe drinking water is the responsibility of government. Around 1.1 billion people in world have no access to safe drinking water (Programme, 2003). In under developed countries many individuals don't have approach to clean drinking water that is the reason of existence of more health problems. In developing countries death of 5 million children resulted due to ill quality of water (Amr and Yassin, 2008; Van Leeuwen, 2000). Pakistan also falls in the list of developing countries and facing the problem of availability, usage and management of drinking water. In Pakistan groundwater is used as drinking water and utilized through hand pumps, tube well and open wells. Approximately 66\% of water is supplied through piped system (MDG, 2009). Poor water quality is responsible for $30 \%$ of all diseases and $60 \%$ of all deaths (Asia, 2000). Among children and toddlers the most predominant disease caused by contaminated water is diarrhoea leading to the death, while every fifth occupant suffers from many ailments is due to the drinking of filthy water (Kahlown et al., 2006; Mohsin et al., 2013).

Numerous studies showed that in different cities of Punjab people are drinking contaminated water due to several reasons (Economy, 2005). Different chemical and biological contaminations affect the drinking water quality in Pakistan. In different cities elevated levels of arsenic, fluoride and nitrate have been observed (Cheema, 2013). Moreover, lead levels even exceeded WHO limits (Ul Haq et al., 2011). Further studies have detected the presence of microorganisms in drinking water samples from Lahore (Anwar et al., 2017; Hannan et al., 2010).

Lahore is one of the largest cities of Pakistan. Water and 
Sanitation Agency (WASA) is responsible to supply water in Lahore (Hamid et al., 2013). A recent study revealed that water aquifer of Lahore is depleting as years back when Pakistan was created, the water table in Lahore city was at the depth of 15-16 feet that has now extended its depth up to 100 feet. Moreover, the quality of water is also depleting biologically and chemically as water in at all areas of Lahore does not meet drinking water standards. It is observed that industrial waste, air pollution, Sewage and street runoff are major contributors of the contamination of water (Hassan et $a l .$, 2016). Lahore is subdivided into nine towns. The aim of this study was to determine the quality of water supplied by WASA to residents in the western part of Lahore by making the comparison with the permissible limits of drinking water provided by WHO and water quality standards of Pakistan and to find out Water quality index. For this purpose, Geographical Information System (GIS) technology was used to create spatial map of each sampling site.

\section{MATERIALS AND METHODS}

Study area: Lahore is located at $31^{\circ} 32^{\prime} 59^{\prime \prime} \mathrm{N}$ and $74^{\circ} 20^{\prime} 37^{\prime \prime} \mathrm{E}$. This study mainly focuses on Western part of Lahore covering the urban areas in major having residential industrial and commercial parts. Sabzazar, Allama iqbal town, Johar town, Samnabad, Ichrra, Green town, Township, Farrukhabad, Shadbagh, Old City, Misri shah, Data nagar, Shahadra, Baghbanpura, Mughalpura, Mustafa abad, Mozang, Ravi road, Gulberg, Shimla hill, Krishan nagar, Anarkali and Taj pura are major places here. The study area is divided into six zones as per Figure 1.

Water sampling: For convenience and proper identification of each sample the study area was divided into six zones each containing twelve sampling sites that gave a total of 72

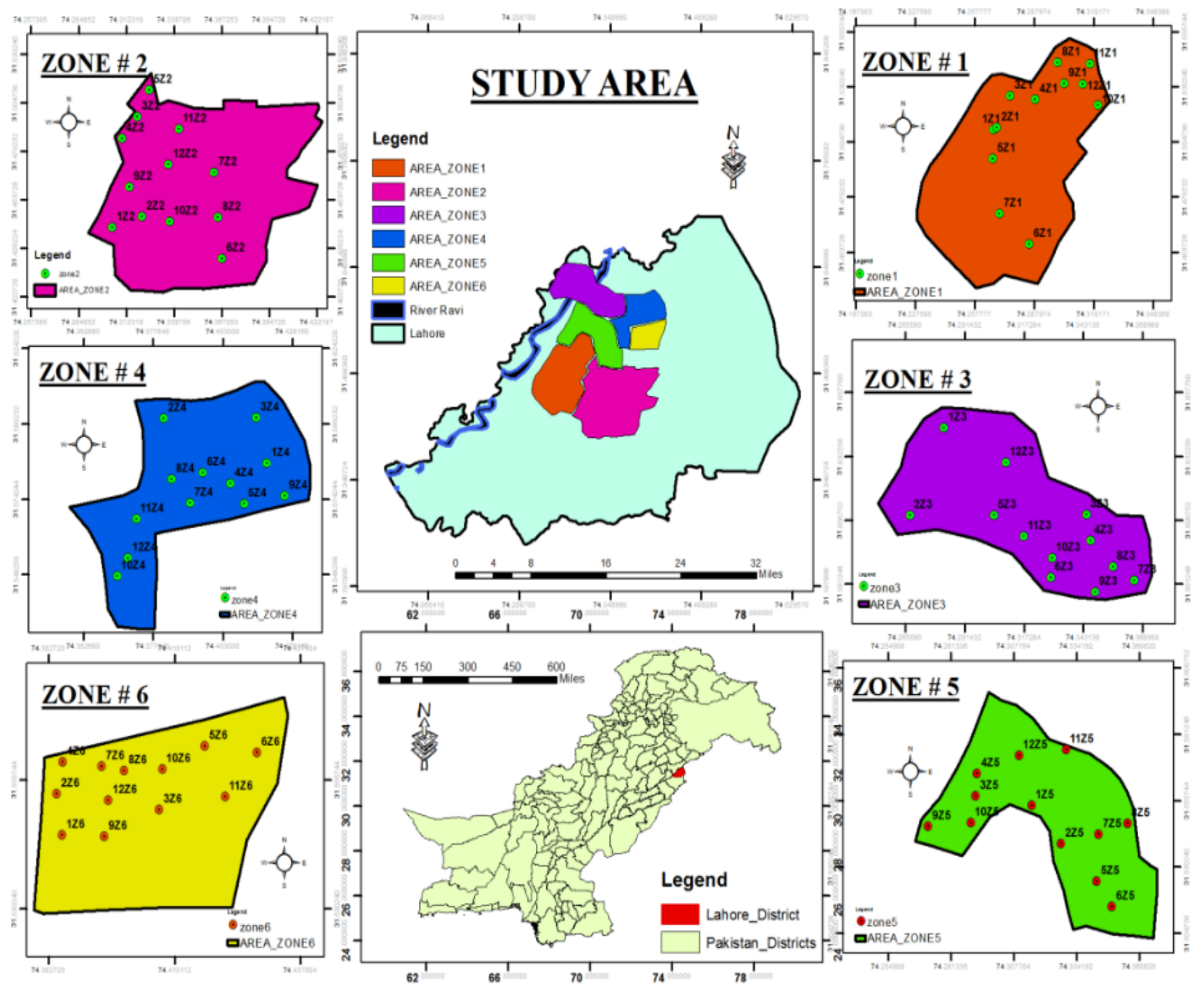

Figure 1. Study area showing sampling locations in six zones. 
samples. These zones were named as Zone 1 (1Z1, 2Z1, 3Z1, 4Z1, 5Z1, 6Z1, 7Z1, 8Z1, 9Z1, 10Z1, $11 Z 1$ and 12Z1), Zone 2 (1Z2, 2Z2, 3Z2, 4Z2, 5Z2, 6Z2, 7Z2, 8Z2, 9Z2, 10Z2, $11 \mathrm{Z2}$ and 12Z2), Zone 3 (1Z3, 2Z3, 3Z3, 4Z3, 5Z3, 6Z3, 7Z3, 8Z3, 9Z3, 10Z3, $11 \mathrm{Z3}$ and 12Z3), Zone 4 (1Z4, 2Z4, 3Z4, 4Z4, 5Z4, 6Z4, 7Z4, 8Z4, 9Z4, 10Z4, $11 Z 4$ and 12Z4), Zone 5 (1Z5, 2Z5, 3Z5, 4Z5, 5Z5, 6Z5, 7Z5, 8Z5, 9Z5, 10Z5, $11 \mathrm{Z5}$ and 12Z5) and Zone 6 (1Z6, 2Z6, 3Z6, 4Z6, 5Z6, 6Z6, 7Z6, 8Z6, 9Z6, 10Z6, $11 Z 6$ and 12Z6). Groundwater samples for the month of November, 2016 were collected directly from tube wells by following the standard procedures for the year of 2016 in cleaned plastic bottles. Location of each sampling point was recorded by GPS (Global Positioning System). These samples were brought to water testing laboratory of the university in order to conduct analytical procedure.

Analytical methods: Each water sample was tested for the 12 physicochemical parameters $(\mathrm{pH}$, turbidity, TDS, Electrical conductivity, Total hardness, $\mathrm{Ca}, \mathrm{Mg}$, Total alkalinity, $\mathrm{Cl}$, $\mathrm{NO}, \mathrm{CO}, \mathrm{HCO}$ ) by following standard procedures. $\mathrm{pH}$ and electrical conductivity (EC) were determined by using $\mathrm{pH}$ meter and conductivity meter respectively. Soluble cations $\left(\mathrm{Ca}^{2+}, \mathrm{Mg}^{2+}\right)$ and soluble anions $\left(\mathrm{Cl}^{-}, \mathrm{Co} \mathrm{HCO}_{3}^{-},\right)$were measured by titration method (Jain, 1976). Turbidity was determined by using a calibrated turbidimeter unit, total dissolved solids (TDS) were determined according to standard method as given by (Eaton et al., 2005).

Spatial and statistical methods: Descriptive statistics and correlation was applied in Microsoft excel 2010. Spatial distribution for all parameters at each location was estimated by using Inverse Distance Weight (IDW) technique in GIS environment by using Arc Map (10.2). IDW was preferred over other interpolation techniques (Krigging and Cokrigging) because it is simply spatial autocorrelation technique while Krigging is a complex technique applied on sophisticated datasets. Another advantage of IDW is that there is no threshold for number of points used in the interpolation (Setianto and Triandini, 2013).

Calculation of water quality index (WQI): Horton was the person who devised WQI in 1965 (Horton, 1965). The purpose for the calculation of WQI is to convert complicated water quality data taken from physicochemical analysis for different parameters into usable and understandable information. Hence, WQI plays significant role for the categorization of water in good or bad. In this study Weighted Arithmetic Index method was used to determine WQI (Cude, 2001). Out of 12 parameters under consideration in this study four parameters i.e.; Alkalinity, bicarbonate (Absence of WHO standard values), carbonate and nitrate (not detected in sampling), were skipped and remaining 8 were incorporated into the model. In the first step Quality Ranging Scale $\left(Q_{i}\right)$ for each parameter was calculated using following equation:

$$
\mathrm{Q}_{\mathrm{i}}=\left\{\left[\left(\mathrm{V}_{\text {observed }}-\mathrm{V}_{\text {ideal }}\right) /\left(\mathrm{S}_{\mathrm{i}}-\mathrm{V}_{\text {ideal }}\right)\right] * 100\right\}
$$

Where, $\mathrm{Q}_{\mathrm{i}}=$ Quality rating of ith parameter for a total of $\mathrm{n}$ water quality parameters; $\mathrm{V}$ observed= value obtained from laboratory analysis of certain parameter; $\mathrm{V}_{\text {ideal }}=$ Ideal value of that water quality parameter can be obtained from the standard Tables.

$\mathrm{V}$ ideal for $\mathrm{pH}=7$ and for other parameters it equals zero,

$\mathrm{S}_{\mathrm{i}}=$ Recommended WHO standard of the water quality parameter.

In step number two Relative Unit weight $\left(\mathrm{W}_{\mathrm{i}}\right)$ was calculated by the given formulae:

$$
\mathrm{W}_{\mathrm{i}}=\mathrm{I} / \mathrm{S}_{\mathrm{i}}
$$

Where, $\mathrm{I}=$ proportionality constant that can be calculated by

$$
\mathrm{I}=\frac{1}{\Sigma 1 / \mathrm{Si}}
$$

It means the $\mathrm{Wi}$ is inversely proportional to recommended standard value.

In final step WQI was obtained from following equation

$$
\mathrm{WQI}=\Sigma \mathrm{Q}_{\mathrm{i}} \mathrm{W}_{\mathrm{i}} / \Sigma \mathrm{W}_{\mathrm{i}}
$$

Where, $\mathrm{Q}_{\mathrm{i}}=$ Quality rating; $\mathrm{W}_{\mathrm{i}}=$ Relative weight

Basically WQI was defined according to use of water. For irrigation WQI threshold is different but for current study quality of water was assessed for human consumption and use (Khwakaram, Majid, Ahmed, and Hama, 2015; Tyagi, Sharma, Singh, and Dobhal, 2013)

\section{RESULTS AND DISCUSSION}

\section{Physicochemical Parameters:}

pH: $\mathrm{pH}$ of drinking water is quiet important parameter with respect to quality testing. Water with extreme $\mathrm{PH}$ levels poses effects like eye allergy, skin allergy and irritation to internal lining of mucosal membranes (Group, 1986). In study area pH values ranged between 7.8-8.3 with mean value of 7.94 for zone $1,7.8-8$ with mean value of 7.88 for zone $2,7.8-8.3$ with mean value of 7.98 for zone $3,7.8-8.1$ with mean value of 7.88 for zone $4,7.8-8.2$ with mean value of 7.93 for zone 5 and 7.8-8.1 with mean value of 7.86 for zone6 (Fig. 2, 3, 4, 5, $6,7)$. According to WHO standards and NDWQS all the samples have $\mathrm{pH}$ within safe limits (Table 1). So, water from all six zones are $100 \%$ fit for drinking purpose (Table 3).

Turbidity: Turbidity is taken as an aesthetic parameter for drinking water quality. The inclusion of silt, clay and organic suspended particles (Group, 1986). The turbidity for all the sampling sites in zone 1 varied between $0-1.8$ with the average of $0.47 \mathrm{NTU}$, zone 2 varied between $0-2.76$ with the average of $0.47 \mathrm{NTU}$, zone 3 varied between $0-1.1$ with the average of $0.45 \mathrm{NTU}$, zone 4 varied between $0-3.8$ with the average of $0.78 \mathrm{NTU}$, zone 5 varied between $0-3.46$ with the average of $0.65 \mathrm{NTU}$ and zone 5 varied between $0-0.87$ with the average of 0.44 NTU (Figure 2, 3, 4, 5, 6, 7 and table 1). According to WHO standards and NDWQS all the samples have $\mathrm{pH}$ within safe limits. So, all the samples from six zones are $100 \%$ fit for drinking purpose (Table 3 ).

TDS: Total dissolved solid determines the saline behaviour of drinking water. Its value depends on weather, type of rock mass and the time groundwater resides within geological 
Table 1. Mean, range and standard deviation of drinking water quality parameters along with WHO (WHO, 2008) and Pakistan's guidelines for drinking water quality (GoP, 2008).

\begin{tabular}{|c|c|c|c|c|c|c|c|c|c|c|c|c|}
\hline $\begin{array}{l}\text { Parameter } \\
\text { (Unit) }\end{array}$ & pH & $\begin{array}{l}\text { Turbidity } \\
\text { (NTU) }\end{array}$ & TDS (ppm) & $\begin{array}{c}\text { E.C } \\
(\mu \mathrm{S} / \mathrm{cm})\end{array}$ & $\begin{array}{c}\text { Total } \\
\text { Hardness } \\
(\mathrm{ppm})\end{array}$ & $\mathrm{Ca}^{2+}(\mathrm{ppm})$ & $\begin{array}{l}\mathrm{Mg}^{2+} \\
(\mathrm{ppm})\end{array}$ & $\begin{array}{c}\text { Total } \\
\text { Alkalinity }\end{array}$ & $\begin{array}{c}\mathrm{Cl}^{-} \\
(\mathbf{p p m})\end{array}$ & $\begin{array}{c}\mathrm{NO}_{2}^{-} \\
)(\mathbf{p p m})\end{array}$ & $\begin{array}{c}\mathrm{CO}_{3}{ }^{2} \\
\left(\mathrm{ppm}^{2}\right)\end{array}$ & $\begin{array}{l}\mathrm{HCO}_{3}^{-} \\
(\mathrm{ppm})\end{array}$ \\
\hline Mean & 7.94 & 0.47 & 469.44 & 702.33 & 176.83 & 35.40 & 20.94 & 220 & 49.58 & N.D & N.D & 220 \\
\hline Range & $7.8-8.3$ & $0-1.8$ & $245.7-754$ & $334-1198$ & $74-404$ & $12.8-68.8$ & $7.2-55.7$ & $126-590$ & $13-105$ & N.D & N.D & $126-590$ \\
\hline S.D & 0.20 & 0.63 & 177.26 & 303.83 & 98.63 & 17.62 & 13.93 & 127.44 & 31.65 & N.D & N.D & 127.44 \\
\hline Mean & 7.88 & 0.47 & 543.69 & 865.25 & 182.00 & 31.32 & 23.97 & 278.05 & 32 & N.D & N.D & 278.05 \\
\hline Range & $7.8-8$ & $0-2.76$ & $342-875$ & 544-1389 & $66-260$ & $16-45.6$ & $5.7-34.5$ & $22.6-446$ & $17-54$ & N.D & N.D & $22.6-446$ \\
\hline S.D & 0.10 & 0.83 & 180.62 & 285.46 & 56.85 & 9.06 & 8.19 & 115.40 & 12.56 & N.D & N.D & 115.40 \\
\hline Mean & 7.98 & 0.45 & 293.28 & 465.58 & 176.92 & 62.93 & 18.53 & 196.33 & 31.25 & N.D & N.D & 196.33 \\
\hline Range & $7.8-8.3$ & $0-1.1$ & $161.2-510.9$ & $256-811$ & $114-258$ & $23.2-296$ & $11-32.6$ & $108-316$ & $8-98$ & N.D & N.D & $108-316$ \\
\hline S.D & 0.16 & 0.36 & 123.53 & 196.07 & 51.21 & 74.95 & 6.01 & 60.52 & 25.37 & N.D & N.D & 60.52 \\
\hline Mean & 7.88 & 0.78 & 405.78 & 644.17 & 152.92 & 28.07 & 17.14 & 222.33 & 20.97 & N.D & N.D & 222.33 \\
\hline Range & $7.8-8.1$ & $0-3.8$ & $240.6-556.2$ & $382-883$ & $72-265$ & $12.8-41.6$ & $9.6-27.8$ & $126-402$ & $11-36$ & N.D & N.D & $126-402$ \\
\hline S.D & 0.10 & 1.11 & 76.71 & 121.77 & 56.41 & 9.07 & 5.59 & 89.31 & 7.07 & N.D & N.D & 89.31 \\
\hline Mean & 7.93 & 0.65 & 470.71 & 747.25 & 196.67 & 39.20 & 23.67 & 211.57 & 47.33 & N.D & N.D & 211.57 \\
\hline $\operatorname{Max}$ & $7.8-8.2$ & $0-3.46$ & 199-1099.2 & $316-1745$ & $60-468$ & $12.8-89.6$ & $6.72-58.6$ & $38.8-368$ & $13-188$ & N.D & N.D & $38.8-368$ \\
\hline S.D & 0.16 & 1.18 & 288.74 & 458.35 & 132.05 & 25.18 & 16.96 & 83.94 & 49.53 & N.D & N.D & 83.94 \\
\hline Mean & 7.86 & 0.44 & 438.8 & 711.58 & 165 & 32.26667 & 22.40833 & 301.3333 & 20.66 & N.D & N.D & 298.33 \\
\hline Max & $7.8-8.1$ & $0-0.87$ & $282-723.2$ & $448-1148$ & $12-256$ & $16.8-43.2$ & $12-36$ & $194-400$ & $14-32$ & N.D & N.D & $194-400$ \\
\hline S.D & 0.12 & 0.35 & 120.98 & 188.95 & 69.81274 & 9.085186 & 7.53615 & 75.35773 & 5.64 & N.D & N.D & 73.41 \\
\hline \multirow{2}{*}{$\begin{array}{c}\text { WHO } \\
\text { Standards }\end{array}$} & $6.5-8.5$ & $<5$ & $<1000$ & 1000 & N/A & 100 & $<150$ & N/A & 250 & 3 & 500 & N/A \\
\hline & & & & & & & & & & & & \\
\hline NSDWQ & $6.5-8.5$ & $<5$ & $<1000$ & 1000 & $<500$ & 200 & N/A & N/A & $<250$ & $\leq 3$ & 500 & N/A \\
\hline
\end{tabular}

Table 2. Correlation among physicochemical parameters of water.

\begin{tabular}{|c|c|c|c|c|c|c|c|c|c|c|c|c|}
\hline & pH & Turbidity & TDS & EC & $\begin{array}{c}\text { Total } \\
\text { Hardness }\end{array}$ & $\mathrm{Ca}^{2+}$ & $\mathbf{M g}^{2+}$ & $\begin{array}{c}\text { Total } \\
\text { Alkalinity }\end{array}$ & $\mathrm{Cl}^{-}$ & $\mathrm{NO}_{2}^{-}$ & $\mathrm{CO}_{3}{ }^{2}$ & $\mathrm{HCO}_{3}^{-}$ \\
\hline pH & 1 & & & & & & & & & & & \\
\hline Turbidity & -0.18 & 1 & & & & & & & & & & \\
\hline TDS & -0.46 & 0.20 & 1 & & & & & & & & & \\
\hline E.C & -0.48 & 0.19 & $0.98^{* *}$ & 1 & & & & & & & & \\
\hline Total Hardness & -0.42 & 0.30 & 0.62 & 0.64 & 1 & & & & & & & \\
\hline $\mathrm{Ca}^{2+}$ & -0.12 & 0.05 & 0.07 & 0.08 & 0.35 & 1 & & & & & & \\
\hline $\mathbf{M g}^{2+}$ & -0.43 & 0.30 & 0.67 & 0.70 & $0.93^{* *}$ & 0.29 & 1 & & & & & \\
\hline Total Alkalinity & -0.38 & 0.05 & 0.40 & 0.42 & 0.57 & 0.11 & 0.62 & 1 & & & & \\
\hline $\mathrm{Cl}^{-}$ & -0.15 & 0.39 & 0.64 & 0.64 & 0.69 & 0.24 & 0.67 & 0.26 & 1 & & & \\
\hline $\mathrm{NO}_{2}^{-}$ & 0 & 0 & 0 & 0 & 0 & 0 & 0 & 0 & 0 & 1 & & \\
\hline $\mathrm{CO}_{3}{ }^{2}$ & 0 & 0 & 0 & 0 & 0 & 0 & 0 & 0 & 0 & 0 & 1 & \\
\hline $\mathrm{HCO}_{3}^{-}$ & -0.38 & 0.05 & 0.40 & 0.42 & 0.57 & 0.11 & 0.62 & 1.00 & 0.27 & 0 & 0 & 1 \\
\hline
\end{tabular}

${ }^{* * *}$ Correlation is significant at the 0.01 level (2-tailed); ${ }^{*}$ Correlation is significant at the 0.05 level (2-tailed); TDS (Total dissolved solids), EC (Electrical

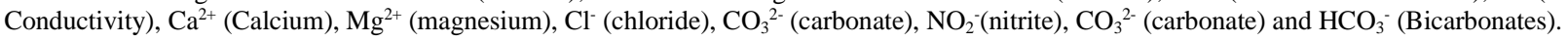

matrix (Shrinivasa and Venkateswaralu, 2000).TDS in zone 1 varied from $245.7-754$ with the mean value $469.44 \mathrm{ppm}$, in zone 2 the variation occurred from 342-875 with the mean value $543.69 \mathrm{ppm}$, in zone 3 it varied from 161.2-510.9 with average of $293.28 \mathrm{ppm}$, in zone 4 it varied from $240.6-556.2$ with mean value of $405.78 \mathrm{ppm}$, in zone 5 the variation is from 199-1099.2 with average of $470.71 \mathrm{ppm}$ and in zone 6 the variation ranged between 282-723.2 with average of 438.8 ppm (Fig. 2, 3, 4, 5, 6, 7 and table 1). All the samples are within the safe limits of WHO and NSDWQ except in zone 5 where the sample from location $11 \mathrm{Z5}$ (Anarkali) exceeds permissible limit. So, the water samples from Zone 1, zone 2, zone 3, zone 4, and zone 6 are $100 \%$ fit for human consumption but water from zone 5 is $91.67 \%$ fit (Table 3 ). From Table 2, it is clear that TDS have a strong positive correlation $(\mathrm{r}>0.7, \mathrm{p}=0.001)$ with $\mathrm{EC}$ that indicate increase in salt content.

Hardness: Hardness results in drinking water due to increased concentration of calcium and magnesium. It prevents water to precipitate with cleanser and increase the boiling point of water (Trivedy and Goel, 1984). In this study hardness for zone 1 varied from 74-404 with average of $176.83 \mathrm{ppm}$, for zone 2 varied from 66-260 with mean value $182 \mathrm{ppm}$, for zone 3 varied from 114-258 with average of $176.92 \mathrm{ppm}$, for zone 4 it varied from 72-265 with average of $152.92 \mathrm{ppm}$, for zone 5 it varied from 60-468 with average of $196.67 \mathrm{ppm}$ and for zone 6 it varied from 12-256 with average of 165 ppm (Fig. 2, 3, 4, 5, 6, 7 and Table 1). All the samples are within safe limits of WHO and NSDWQ. So, all the samples from six zones are $100 \%$ fit for drinking purpose (Table 3). From table 2 a strong positive correlation ( $r>0.7$, 
Spatial analysis of groundwater quality

Table 3. Percent distribution of water samples based on different parameters.

\begin{tabular}{|c|c|c|c|c|c|c|c|c|c|c|c|c|c|c|c|c|c|}
\hline \multicolumn{2}{|c|}{ Parameters } & \multicolumn{2}{|c|}{$\mathrm{pH}$} & \multicolumn{2}{|c|}{ Turbidity } & \multicolumn{2}{|c|}{ TDS } & \multicolumn{2}{|c|}{ EC } & \multicolumn{2}{|c|}{ Hardness } & \multicolumn{2}{|c|}{$\mathrm{Ca}^{2+}$} & \multicolumn{2}{|c|}{$\mathrm{Mg}^{2+}$} & \multicolumn{2}{|c|}{$\mathrm{Cl}^{-}$} \\
\hline \multirow{13}{*}{ 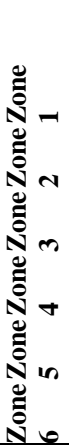 } & & $\begin{array}{l}\text { Fit } \\
(\%)\end{array}$ & $\begin{array}{c}\text { Unfit } \\
(\%)\end{array}$ & $\begin{array}{l}\text { Fit } \\
(\%)\end{array}$ & $\begin{array}{c}\text { Unfit } \\
(\%)\end{array}$ & $\begin{array}{l}\text { Fit } \\
(\%)\end{array}$ & $\begin{array}{c}\text { Unfit } \\
(\%)\end{array}$ & $\begin{array}{l}\text { Fit } \\
(\%)\end{array}$ & $\begin{array}{c}\text { Unfit } \\
(\%)\end{array}$ & $\begin{array}{l}\text { Fit } \\
(\%)\end{array}$ & $\begin{array}{c}\text { Unfit } \\
(\%)\end{array}$ & $\begin{array}{l}\text { Fit } \\
(\%)\end{array}$ & $\begin{array}{c}\text { Unfit } \\
(\%)\end{array}$ & $\begin{array}{l}\text { Fit } \\
(\%)\end{array}$ & $\begin{array}{c}\text { Unfit } \\
(\%)\end{array}$ & $\begin{array}{l}\text { Fit } \\
(\%)\end{array}$ & $\begin{array}{c}\text { Unfit } \\
(\%)\end{array}$ \\
\hline & WHO & 100 & Nil & 100 & Nil & 100 & Nil & 83.33 & 16.67 & N/A & N/A & 100 & Nil & 100 & Nil & 100 & Nil \\
\hline & NSDWQ & 100 & Nil & 100 & Nil & 100 & Nil & 83.33 & 16.67 & 100 & Nil & 100 & Nil & N/A & N/A & 100 & Nil \\
\hline & WHO & 100 & Nil & 100 & Nil & 100 & Nil & 83.3 & 16.6 & N/A & Nil & 100 & Nil & 100 & Nil & 100 & Nil \\
\hline & NSDWQ & 100 & Nil & 100 & Nil & 100 & Nil & 83.3 & 16.6 & 100 & Nil & 100 & Nil & N/A & Nil & 100 & Nil \\
\hline & WHO & 100 & Nil & 100 & Nil & 100 & Nil & 100 & Nil & N/A & Nil & 91.67 & 8.33 & 100 & Nil & 100 & Nil \\
\hline & NSDWQ & 100 & Nil & 100 & Nil & 100 & Nil & 100 & Nil & 100 & Nil & 91.67 & 8.33 & N/A & Nil & 100 & Nil \\
\hline & WHO & 100 & Nil & 100 & Nil & 100 & Nil & 100 & Nil & N/A & Nil & 100 & Nil & 100 & Nil & 100 & Nil \\
\hline & NSDWQ & 100 & Nil & 100 & Nil & 100 & Nil & 100 & Nil & 100 & Nil & 100 & Nil & N/A & Nil & 100 & Nil \\
\hline & WHO & 100 & Nil & 100 & Nil & 91.67 & 8.33 & 83.33 & 16.67 & N/A & N/A & 100 & Nil & 100 & Nil & 100 & Nil \\
\hline & NSDWQ & 100 & Nil & 100 & Nil & 91.67 & 8.33 & 83.33 & 16.67 & 100 & Nil & 100 & Nil & N/A & N/A & 100 & Nil \\
\hline & WHO & 100 & Nil & 100 & Nil & 100 & Nil & 91.67 & 8.33 & N/A & N/A & 100 & Nil & 100 & Nil & 100 & Nil \\
\hline & NSDWQ & 100 & Nil & 100 & Nil & 100 & Nil & 91.67 & 8.33 & 100 & Nil & 100 & Nil & N/A & N/A & 100 & Nil \\
\hline
\end{tabular}

N/A: No permissible limit available/set so far.

Note: Parameters without standard values (total alkalinity, bicarbonates) and those not detected (nitrite, carbonate) are not mentioned in table.
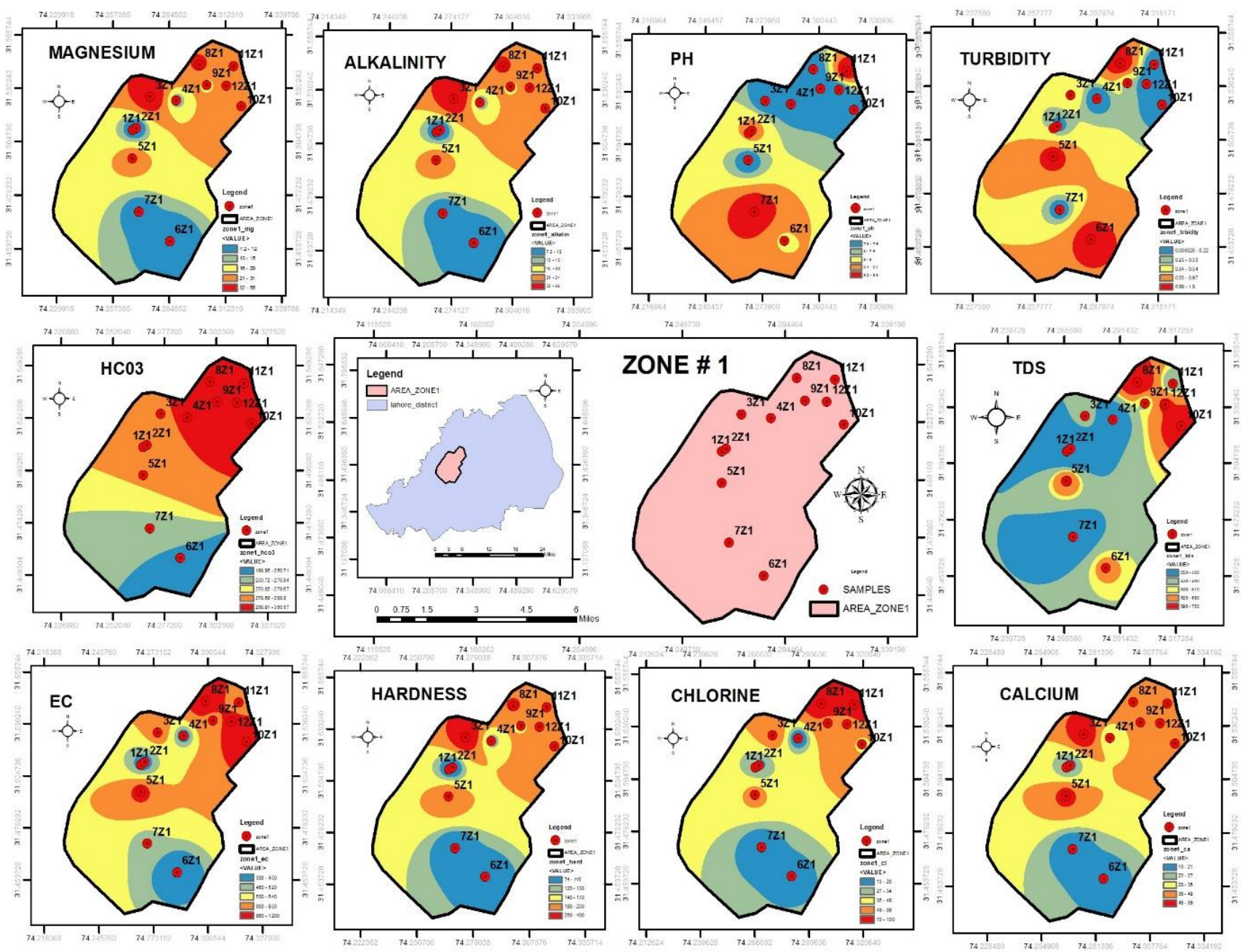

Figure 2. Spatio-temporal variation for all parameters in zone 1.

$\mathrm{p}=0.001$ ) of Hardness with $\mathrm{Mg}^{2+}$ can be observed this is because hardness is directly linked with the presence of $\mathrm{Ca}^{2+}$ and $\mathrm{Mg}^{2+}$.
Alkalinity: Alkalinity is the ability of water to neutralize strong acid it indicates the presence of bicarbonate, carbonate and hydroxide components (Patil and Patil, 2010). Alkalinity 

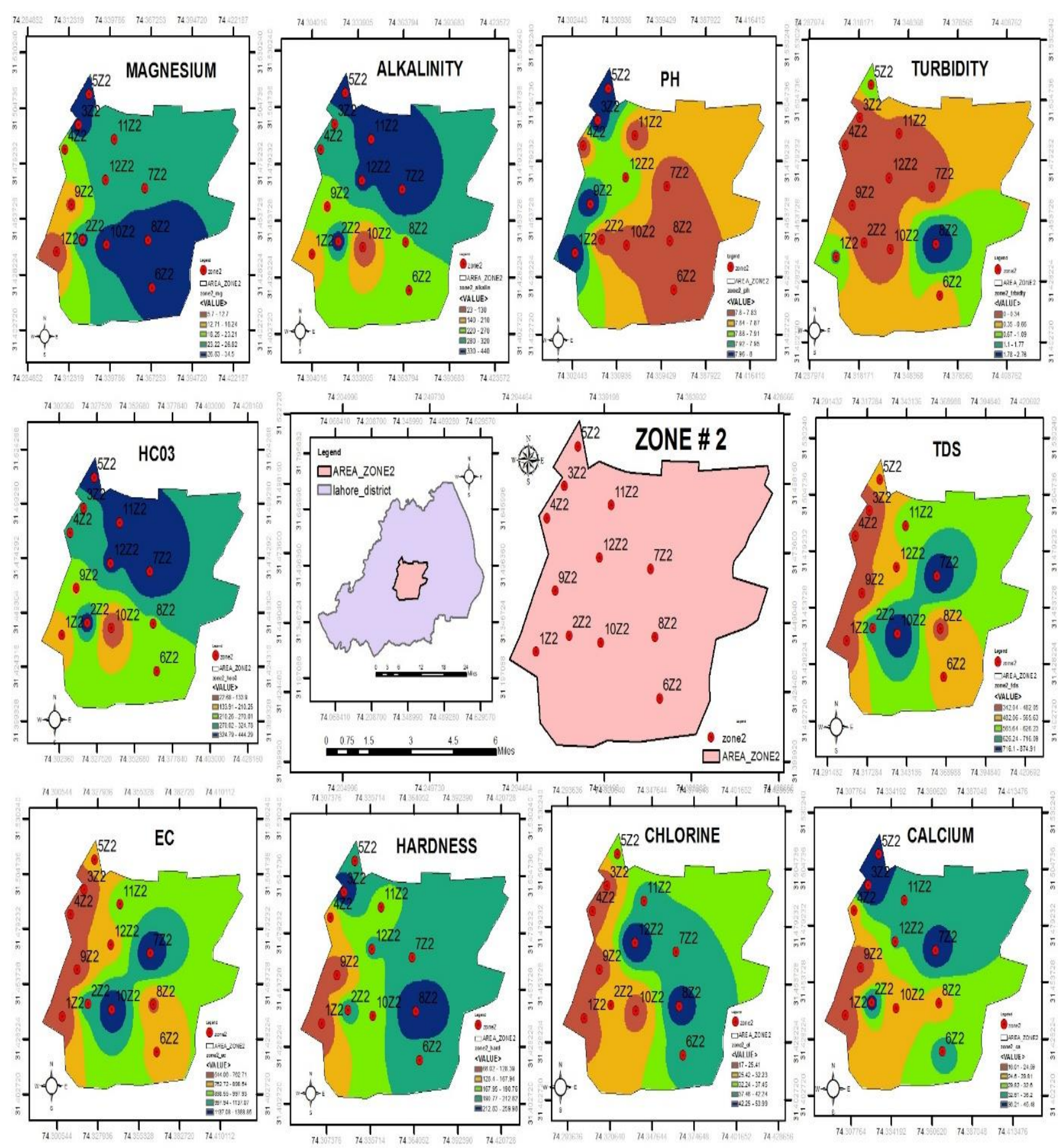

Figure 3. Spatio-temporal variation for all parameters in zone 2.

analysis of groundwater of zone 1 varied from 126-590 with an average value of $220 \mathrm{ppm}$. For zone 2 it varied from 22.6446 with an average of $278.05 \mathrm{ppm}$. The variation in zone 3 seemed to be $108-316$ with an average value of $196.33 \mathrm{ppm}$. For zone 4 it varied from 126-402 with an average of 222.33 ppm. For zone 5 it varied from 38.8-368 with mean vale $211.57 \mathrm{ppm}$. For zone 6 it varied from 194-400 with mean of 301.3333 ppm (Fig. 2, 3, 4, 5, 6, 7 and Table 1). There are no fixed values for alkalinity by WHO and NSDWQ (Shahid $e t$ al., 2015). 


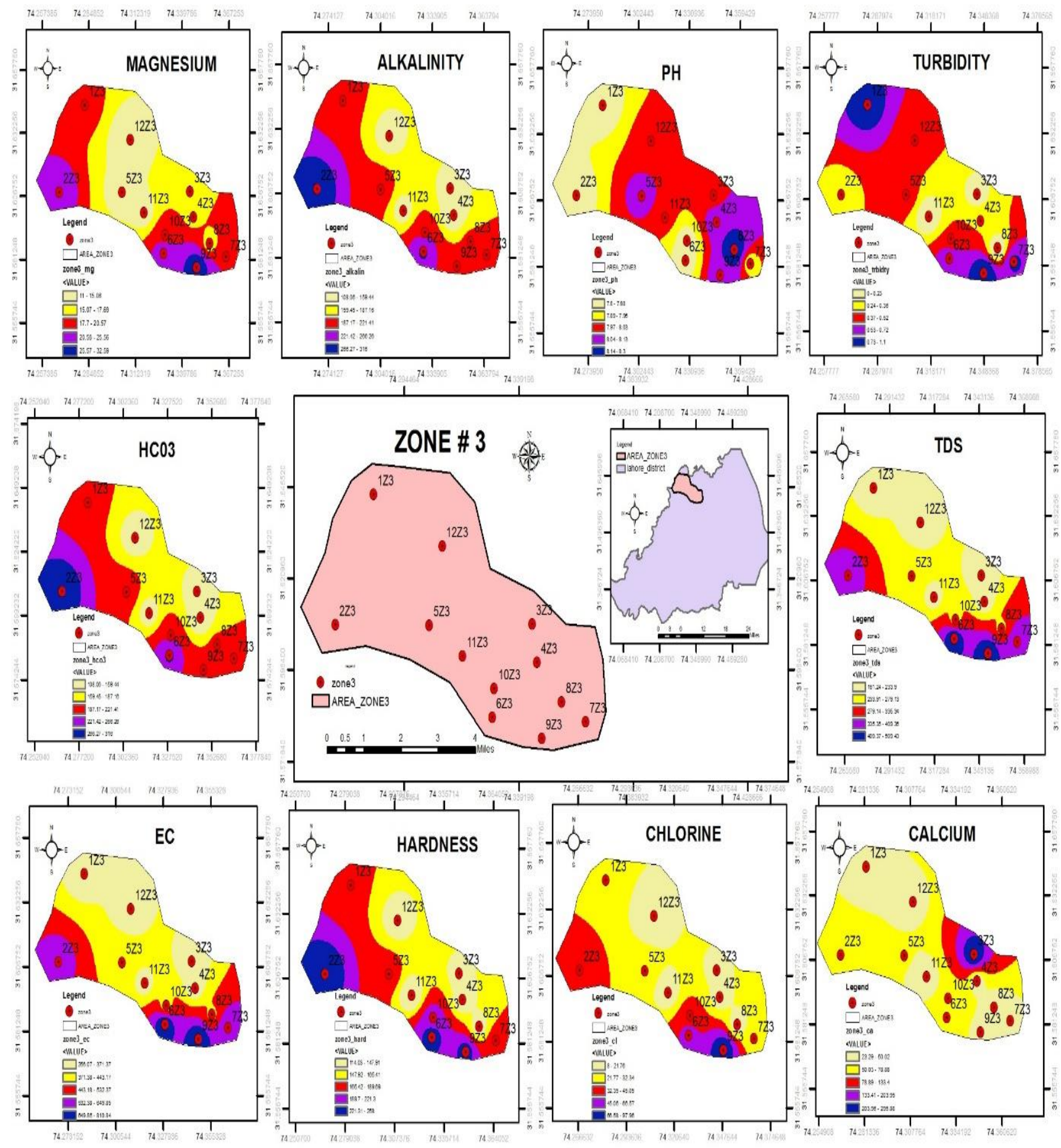

Figure 4. Spatio-temporal variation for all parameters in zone 3.

Calcium and magnesium $\left(\mathrm{Ca}^{2+}, \mathrm{Mg}^{2+}\right)$ : Calcium and magnesium are linked with hardness in water. Erosion of rocks like limestone and dolomite and minerals like calcite and magnetite is common source of $\mathrm{Mg}$ and $\mathrm{Ca}^{2+}$ in groundwater (Jha et al., 2007). Calcium values in study area varied between 12.8-68.8, 16-45.6, 23.2-296, 12.8-41.6, 12.889.6 and 16.8-43.2 for zone 1 , zone 2 , zone 3 , zone 4 , zone 5 and zone 6 respectively (Figure 2, 3, 4, 5, 6, 7 and table 1). 

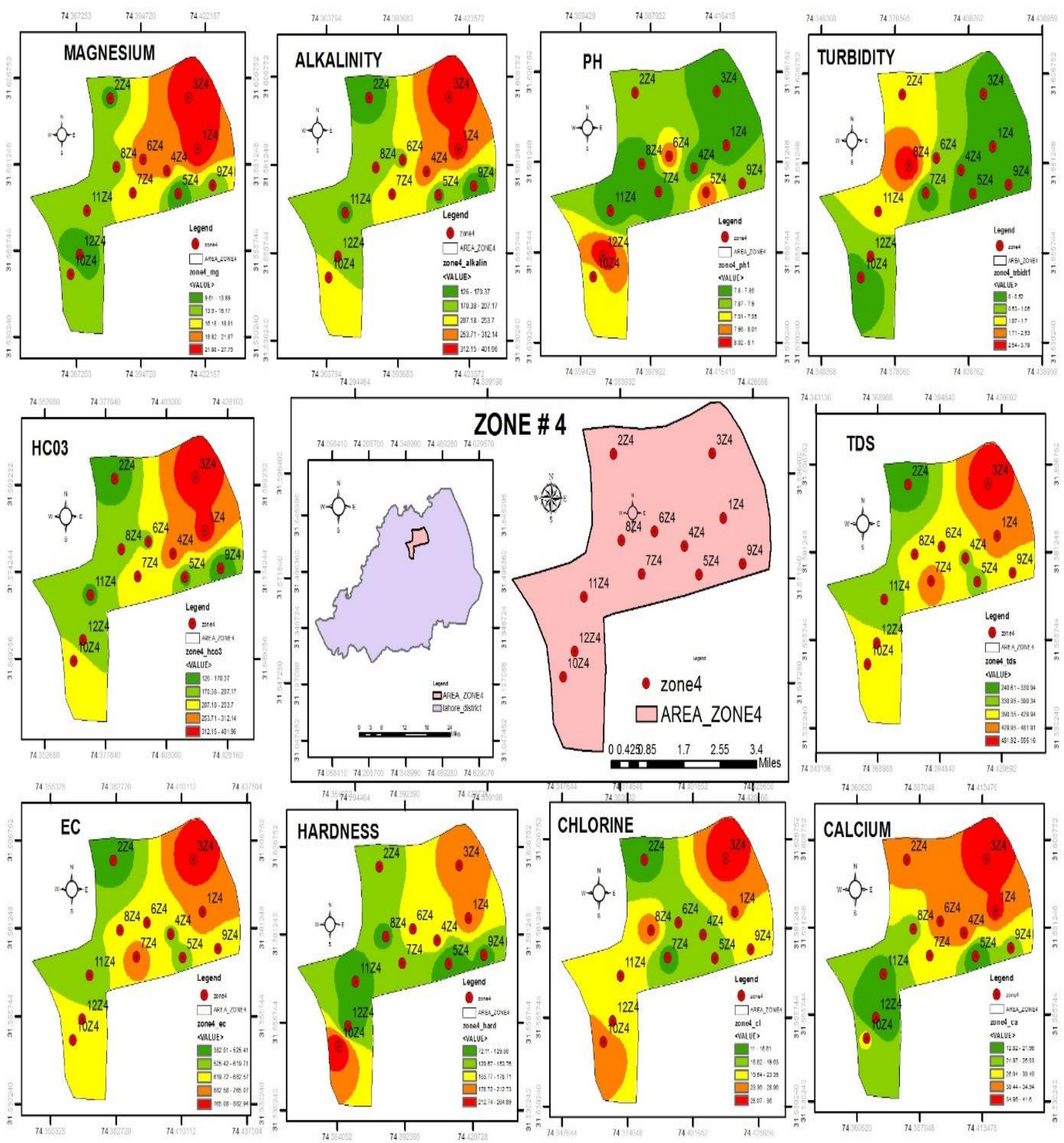

Figure 5. Spatio-temporal variation for all parameters in zone 4.

According to WHO and NSDWQ all zones fall within safe limits of WHO and NSDWQ except for Zone 3 where location $3 Z 3$ (Shadbagh) exceeds the defined limit. Hence, water samples from all zones are $100 \%$ for drinking purpose with the exception to zone 3 where only $91.67 \%$ samples are drinkable (table 3). Magnesium values in study area ranged between 7.2-55.7, 5.7-34.5, 11-32.6, 9.6-27.8, 6.72-58.6 and 12-36 (Fig. 2, 3, 4, 5, 6, 7 and Table 1). All the samples are within the safe limits of WHO and NSDWQ. Therefore, samples from all six zones are $100 \%$ fit for human consumption (Table 3 ). 

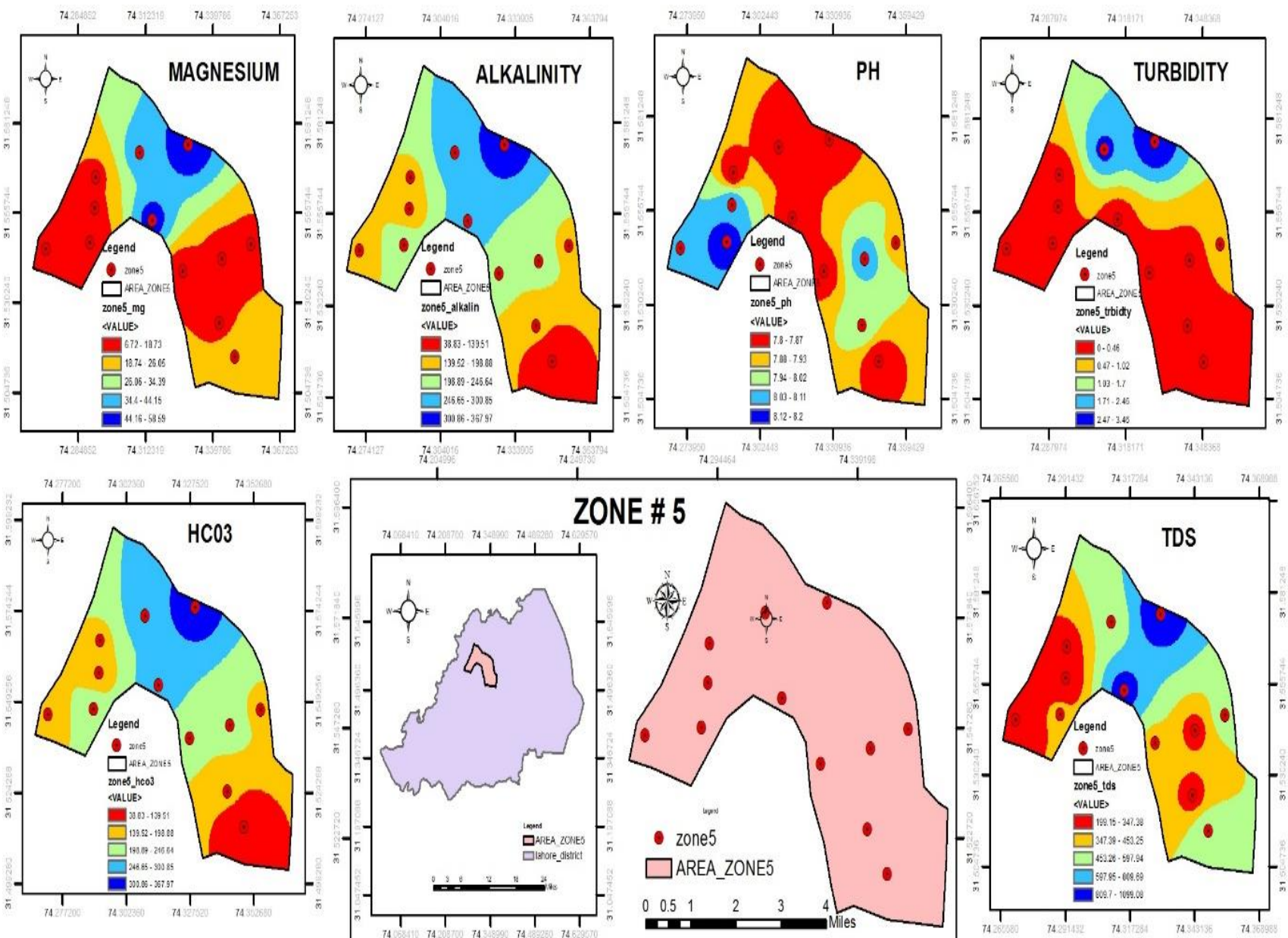

ZONE \# 5
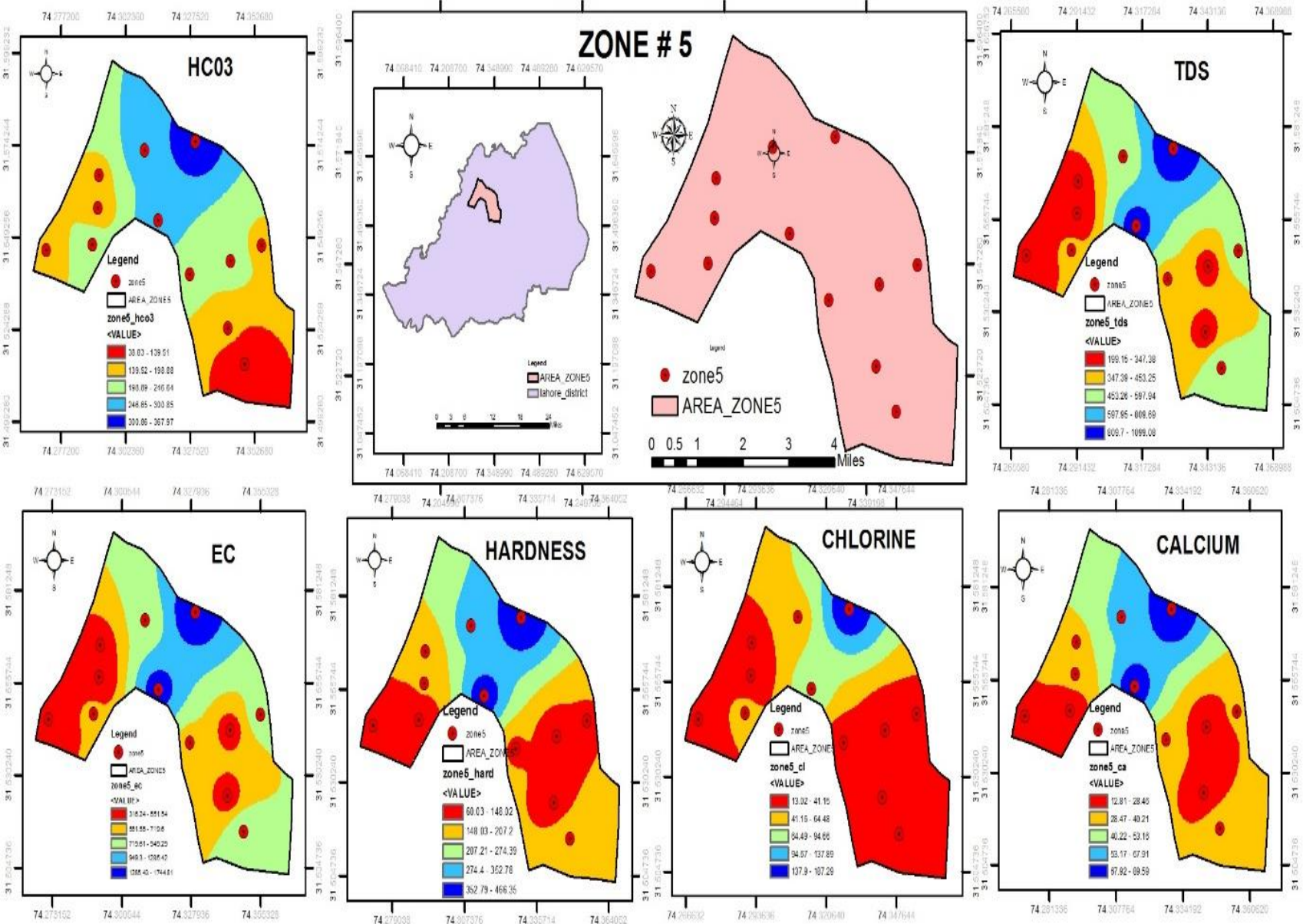

Figure 6. Spatio-temporal variation for all parameters in zone 5.

Chloride: Chloride concentration in drinking water indicates mixing with sewage. People consuming water with high concentrations of chloride can experience laxative effect (Ranjana, 2010). The chloride value in study area ranged between 13-105 with a mean value $49.58 \mathrm{ppm}, 17-54$ with a mean value of $32 \mathrm{ppm}, 8-98$ with a mean value of $31.25 \mathrm{ppm}$,
11-36 with a mean value of $20.97 \mathrm{ppm}, 13-188$ with a mean value of 47.33 and 14-32 with a mean value of $20.66 \mathrm{ppm}$ for zone 1 , zone 2 , zone 3 , zone 4 , zone 5 and zone 6 respectively (Fig. 2, 3, 4, 5, 6, 7 and Table 1). All the values fall within safe limits of WHO an NSDWQ. Thus, water samples from all six zones are safe for human consumption. 

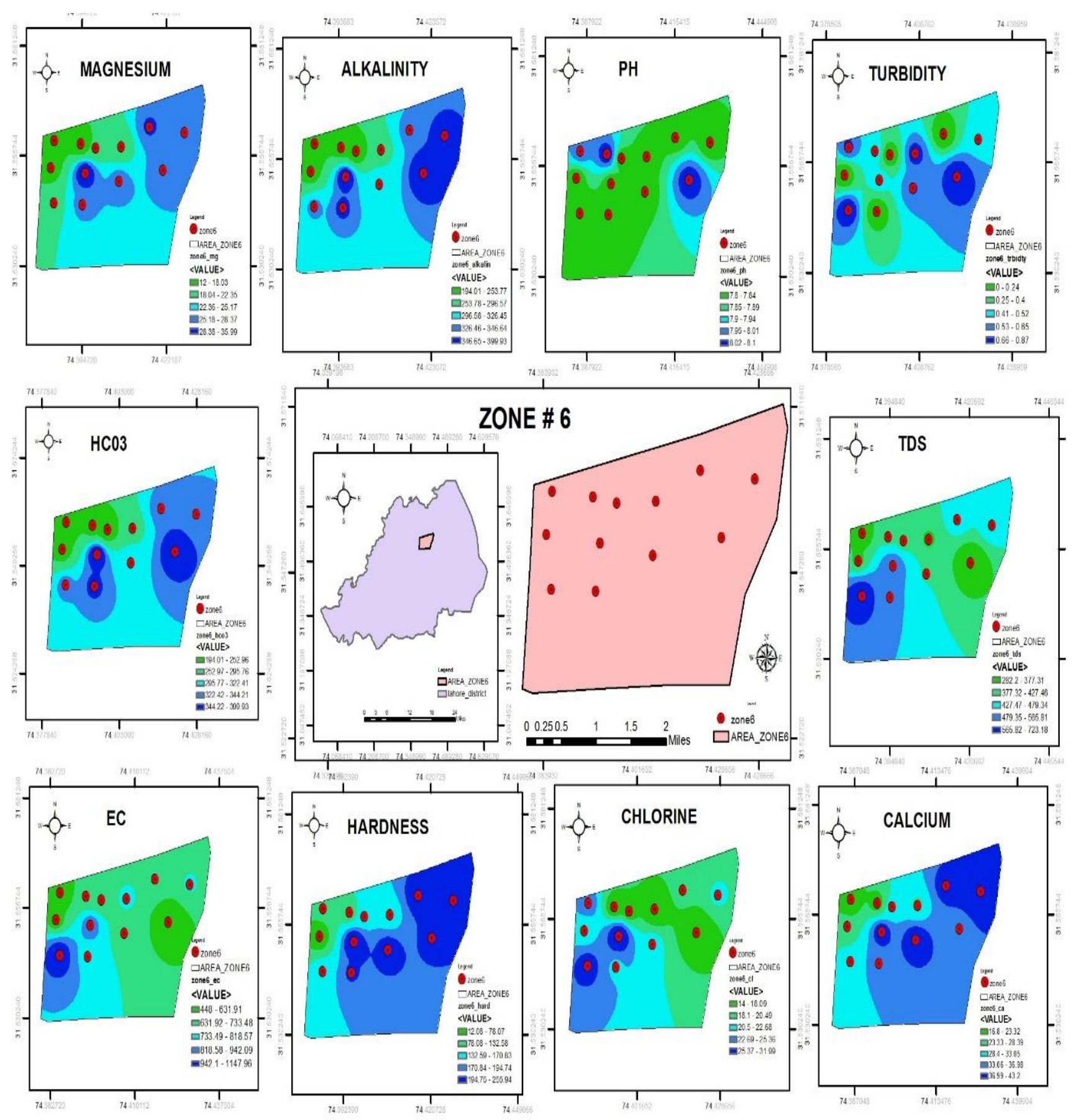

Figure 7. Spatio-temporal variation for all parameters in zone 6.

Electrical conductivity (EC): Electrical conductivity (EC) is capacity of water to possess current. It does not have straight effect on human health. But one can use it to find out mineralization rate and to check the amount of disinfectants used to treat water (Cidu et al., 2011; Kavcar et al., 2009; Khan et al., 2013; Muhammad et al., 2011). EC values in study area varied between 334-1198, 544-1389, 256-811,
382-883, 316-1745and 448-1148 $\mu \mathrm{S} / \mathrm{cm}$ for zone 1 , zone 2 , zone 3 , zone 4, zone 5 and zone 6 respectively (Fig. 2, 3, 4, 5, 6,7 and Table 1). EC in 8Z1, 10Z1, 7Z2, 10Z2, 11Z5, $1 \mathrm{Z6}$ exceeded the permissible limits of WHO and NSDWQ. It is maybe due to the presence of excessive salts as EC measures levels of salts in water (Iqbal et al., 2014). Water samples from remaining location are safe for human consumption. 


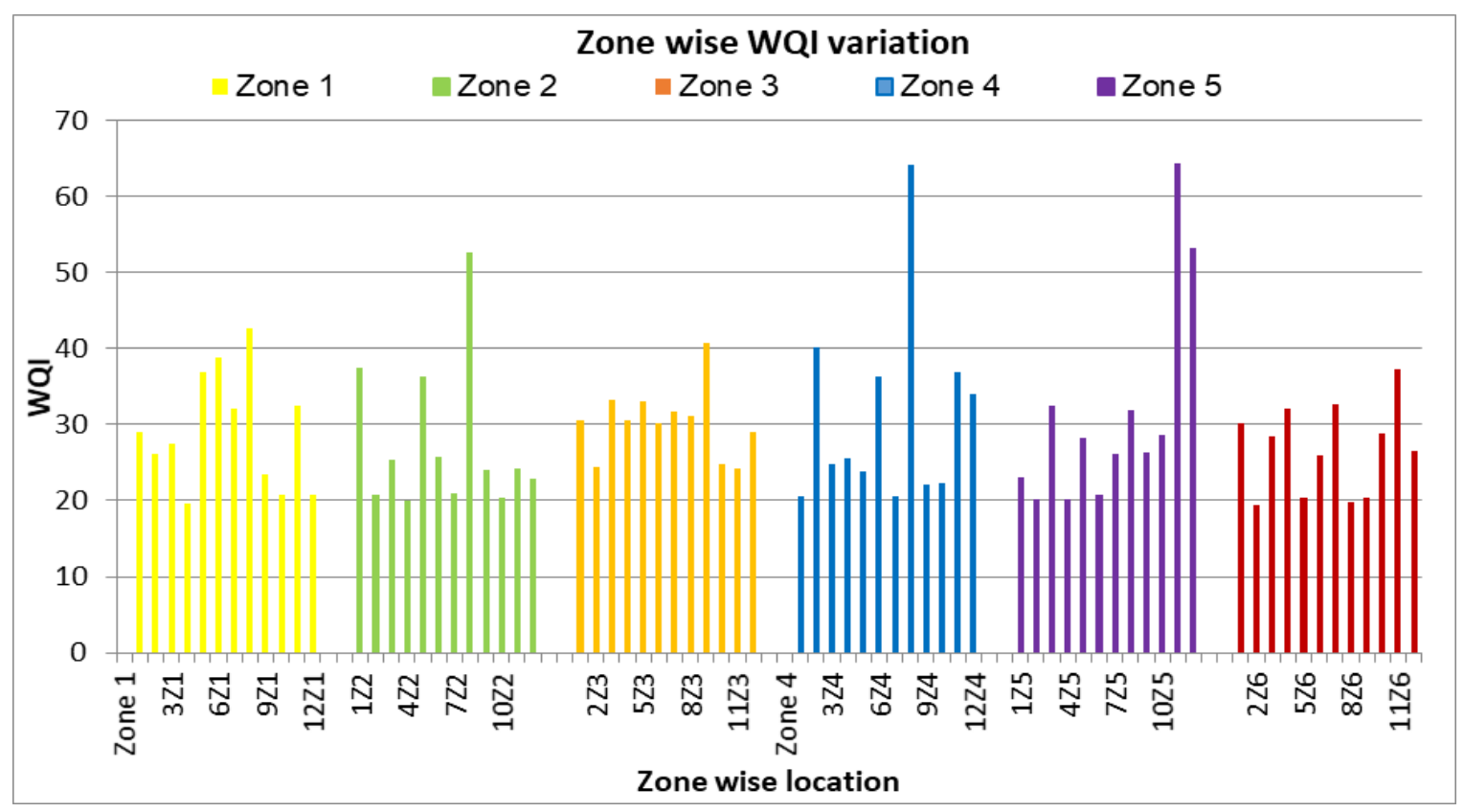

Figure 8. Zone wise Water Quality Index Variation.

Nitrites $\left(\mathrm{NO}^{2-}\right)$ : Nitrite in drinking water is the reduced form of nitrate that has an ability to attach with haemoglobin to form methemoglobin that resists oxygen carrying capacity of blood (Radabaugh and Aposhian, 2000). Nitrite is not detected in a single sample so all the samples are $100 \%$ fit for human consumption (Fig. 2, 3, 4, 5, 6, 7 and Table 1).

Carbonates and bicarbonates: In this study, the amount of carbonates was under the detection level while bicarbonates with high concentrations ranged from $126-590 \mathrm{ppm}$ in zone 1 , 22.6-446 ppm in zone $2,108-316 \mathrm{ppm}$ in zone $3,126-402 \mathrm{ppm}$ in zone $4,38.8-368 \mathrm{ppm}$ in zone 5 and $194-400 \mathrm{ppm}$ in zone 6 (Fig. 2, 3, 4, 5, 6, 7 and Table 1). No standard values are prescribed for carbonates and bicarbonates (Shahid et al., 2015). Therefore, all samples are $100 \%$ fit.

Water quality index (WQI): The WQI in the study area showed that some samples have excellent, some have good and remaining have poor water quality as per Table 4 .

Table 4. Water quality index ratings Source (Tyagi et al., 2013).

\begin{tabular}{ll}
\hline WQI values & Rating of water quality \\
\hline $0-25$ & Excellent water quality \\
$26-50$ & Good Water quality \\
$51-75$ & Poor water quality \\
$76-100$ & Very poor water quality \\
Above 100 & Unsuitable for drinking purpose \\
\hline
\end{tabular}

The results showed that $37.5 \%$ water samples are of excellent quality, $56.9 \%$ are of good quality and $5.5 \%$ are of poor quality this is because the samples from location $8 \mathrm{Z} 2,8 \mathrm{Z} 4$, $11 \mathrm{Z5}$ and $12 \mathrm{Z5}$ have WQI in the range of 51-75 figure. The location $8 \mathrm{Z} 2$ is an industrial state so maybe there is some mixing of industrial effluent with water caused the decrease in water quality. Poor quality in $11 \mathrm{Z5}$ is associated with high values of TDS and EC. According to (Haydar et al., 2016) some areas of Lahore are undergoing bacteriological contamination. Similar results were reported by (Hassan et al., 2016) where water quality is deteriorating at some location and improving in others due to dilution factors.

Conclusions: From this study it is concluded that the Physicochemical quality of water is partially satisfactory as some parameters like TDS, EC, $\mathrm{Ca}^{2+}$ exceeded WHO as well as NSDWQ at some locations. Among all samples 8.33\% samples are not meeting TDS and $16.67 \%$ are not meeting EC permissible range in zone5. Similarly, $8.33 \%$ samples are unfit with respect to $\mathrm{Ca}^{2+}$ in zone3. So, these two zones can be declared as hotspots for this study. The results from WQI revealed that more than half of the samples are of good quality that is acceptable for human consumption but some water samples are of poor quality. The probable reasons for this contamination are poor maintenance of water supply system, broken pipelines and erratic water supply by WASA. Moreover, some of the samples are in industrial area. These problems can be resolved by proper water quality management and with the adoption of updated water treatment technologies.

Acknowledgement: We thank the laboratory staff of College of Earth and Environmental Sciences for helping and guiding in water quality parameters testing. 


\section{REFERENCES}

Amr, S.A. and M.M. Yassin. 2008. Microbial contamination of the drinking water distribution system and its impact on human health in Khan Yunis Governorate, Gaza Strip: seven years of monitoring (2000-2006). Public Health. 122:1275-1283.

Anwar, M.S., S. Lateef and G.M. Siddiqi. 2017. Bacteriological quality of drinking water in Lahore. Biomedica 26:66-69.

Ashraf, S., F. Abbas, M. Ibrahim, U. Rashid, S. Khalid, H.R. Ahmad and T. Majeed. 2015. Application of GIS for the identification and demarcation of selective heavy metal concentrations in the urban groundwater. J. Geogr. Sci. 25:225-235.

Asia, D.S. 2000. Water Vision 2025; Country Report, Pakistan. Maharashtra, India, Global Water Partnership. South Asia Technical Advisory Committee Regional Office.

Cheema, M. 2013. The impact on health and the willingness to pay for piped water in Punjab, Pakistan: Ph.D. Diss., NC. State.Univ., Aleigh, North Carolina, United States.

Cidu, R., F. Frau and P. Tore. 2011. Drinking water quality: Comparing inorganic components in bottled water and Italian tap water. J. Food Comp. Anal. 24:184-193.

Cude, C.G. 2001. Oregon water quality index a tool for evaluating water quality management effectiveness. J. Am. Water. Resour. Assoc. 37:125-137.

Eaton, A.D., L.S. Clesceri, E.W. Rice, A.E. Greenberg and M.A.H. Franson. 2005. Standard Methods for the Examination of Water and Wastewater, $21^{\text {st }}$ Ed. Amer. Public Health Assoc., pp.1368.

MDG. 2009. Millennium Development Goals: Report 2009 (Includes the 2009 Progress Chart): United Nations Publications. Available online at www.un.org/millenniumgoals/pdf/MDG_Report_2009_ ENG.pdf

Group, W.W. 1986. Health impact of acidic deposition. Sci. Total. Environ. 52:157-187.

GoP. 2008. Standards for Drinking Water Quality. (NSDWQ). In Collaboration with Ministry of Health. World Health Organization, UNICEF.

Hassan, G.Z., F.R. Hassan and S. Akhtar. 2016. Environmental issues and concerns of groundwater in Lahore. Proc. Pak. Acad. Sci. B. Life Environ. Sci. 53:163-178.

Hamid, A., G. Yaqub, Z. Sadiq, A. Tahir and N.U. Ain. 2013. Intensive report on total analysis of drinking water quality in Lahore. Int. J. Env. Sci. 3:2161-2162.

Hannan, A., S. Shan and U. Arshad. 2010. Bacteriological analysis of drinking water from 100 families of Lahore by membrane filtration technique and chromagar. BioMedica 26:152-156.
Haque, M.M., A. Rahman, D. Hagare and G. Kibria. 2014. Probabilistic water demand forecasting using projected climatic data for Blue Mountains water supply system in Australia. Water. Resour. Manage. 28:1959-1971.

Haydar, S., M. Arshad and J.A. Aziz. 2016. Evaluation of drinking water quality in urban areas of Pakistan: A case study of Southern Lahore. Pak. J. Eng. Appl. Sci. 5: 1623.

Horton, R.K. 1965. An index number system for rating water quality. J. Water. Pollut. Control Fed. 37:300-306.

House-Peters, L.A. and H. Chang. 2011. Urban water demand modeling: Review of concepts, methods, and organizing principles. Water. Resour. Res. 47:1-15.

Iqbal, H., M. Ishfaq, A. Jabbar, M.N. Abbas, A. Rehaman, S. Ahmad, B.I. Shagufta. 2014. Physico-chemical analysis of drinking water in district Kohat, Khyber Pakhtunkhwa, Pakistan. Int. J. Basic Med. Sci. Pharm. 3:37-41.

Jain, P.C. and J. Monica. 1976. Engineering Chemistry, $15^{\text {th }}$ Ed. Dhanpat Rai Pub. Company Ltd., New Delhi.

Jha, M.K., A. Chowdhury, V. Chowdary and S. Peiffer. 2007. Groundwater management and development by integrated remote sensing and geographic information systems: prospects and constraints. Water. Resour. Manage. 21:427-467.

Kahlown, M., M. Tahir, H. Rasheed and K. Bhatti. 2006. Water Quality Status. National Water Quality Monitoring Programme, $4^{\text {th }}$ Technical Report. Pakistan Council of Research in water Resources.

Kavcar, P., A. Sofuoglu and S.C. Sofuoglu. 2009. A health risk assessment for exposure to trace metals via drinking water ingestion pathway. Int. J. Hyg. Environ. Health 212:216-227.

Khan, S., M. Shahnaz, N. Jehan, S. Rehman, M.T. Shah and I. Din. 2013. Drinking water quality and human health risk in Charsadda district, Pakistan. J. Clean Prod. 60:93101.

Khwakaram, A.I., S.N. Majid, Z.H. Ahmed and N.Y. Hama. 2015. Application of water quality index (WQI) as a possible indicator for agriculture purpose and assessing the ability of self purification process by Qalyasan Stream in Sulaimani City Iraqi Kurdistan Region (IKR). Int. J. Plant Anim. Env. Sci. 5:162-173.

Mohsin, M., S. Safdar, F. Asghar and F. Jamal. 2013. Assessment of drinking water quality and its impact on residents health in Bahawalpur city. Int. J. Human. Soci. Sci. 3:114-128.

Muhammad, S., M.T Shah and S. Khan. 2011. Health risk assessment of heavy metals and their source apportionment in drinking water of Kohistan region, Northern Pakistan. Microchem. J. 98:334-343.

Patil, V. and P. Patil. 2010. Physicochemical analysis of selected groundwater samples of Amalner Town in Jalgaon District, Maharashtra, India. J. Chem. 7:111-116. 
Programme, W.W.A. 2003. Water for People, Water for Life: A joint report by the twenty-three UN Agencies concerned with freshwater: UNESCO.

Radabaugh, T.R. and H.V. Aposhian. 2000. Enzymatic reduction of arsenic compounds in mammalian systems: reduction of arsenate to arsenite by human liver arsenate reductase. Chem. Res. Toxicol. 13:26-30.

Ranjana, A. 2010. Physico-chemical analysis of some groundwater samples of Kotputli town Jaipur, Rajasthan. Int. J. Chem. Env. Pharm. Rech. 1:111-113.

Setianto, A. and T. Triandini. 2013. Comparison of kriging and inverse distance weighted (IDW) interpolation methods in lineament extraction and analysis. J. Appl. Geology 5:21-29.

Shahid, N., Z. Zia, M. Shahid, H.B. Faiq, S. Anwar, G.M. Shah and M.R. Ashraf. 2015. Assessing drinking water quality in Punjab, Pakistan. Pol. J. Environ. Stud. 24: 2597-2606.

Shrinivasa, R.B. and P. Venkateswaralu. 2000. Physicochemical analysis of selected groundwater samples. Ind. J. Environ. Prot. 20:161.166.
Trivedy, R.K. and P.K. Goel. 1984. Chemical and Biological Methods for Water Pollution Studies. Environmental Publications, Karad. pp.1-22.

Tyagi, S., B. Sharma, P. Singh and R. Dobhal. 2013. Water quality assessment in terms of water quality index. J. Am. Water. Resour. Assoc. 1:34-38.

Ul Haq, N., M. Arain, N. Badar, M. Rasheed and Z. Haque. 2011. Drinking water: A major source of lead exposure in Karachi, Pakistan. East Mediterr. Health J. 17:882886.

Van Leeuwen, F. 2000. Safe drinking water: The toxicologist's approach. Food Chem. Toxicol. 38:51-58.

Water, U. 2009. The United Nations World Water Development Report 3- Water in a Changing World. United Nations Educational Scientific and Cultural Organization, Paris.

WHO. 2008. Guidelines for drinking-water quality. Geneva: World Health Organization. 